\title{
Women's Adaptation to Climate Change: An Empirical Study of Housewives related to Food Procurement
}

\author{
Sri Murni Soenarno \\ \{asmurnis@gmail.com\} \\ Universitas Indraprasta PGRI, Jakarta, Indonesia
}

\begin{abstract}
Currently, Indonesia, like other countries in the world, is experiencing the problem of climate change. One of those that are affected by its negative impacts is women, especially housewives. This is because they are the ones who prepare meals in their households. This study aims to understand how women adapt to climate change, especially in maintaining their family's food security. This research is qualitative research. Data collection was carried out through observation, interviews, and documentation. The areas observed were Depok City and Bogor Regency. The conclusion from this research is that women who live in cities and villages have different ways of adapting. Urban women use agricultural technology, while rural women diversify their types of food. This was closely related to the availability of land for their families.
\end{abstract}

Keywords: adaptation, women, climate change

\author{
Adaptasi Perempuan terhadap Perubahan Iklim: Kajian Empiris terhadap Ibu \\ Rumah Tangga terkait Pengadaan Pangan
}

\begin{abstract}
Abstrak. Indonesia saat ini, sama seperti negara-negara lain di dunia, sedang mengalami masalah perubahan iklim. Salah satu yang terkena dampak negatifnya adalah kaum perempuan, khususnya ibu rumah tangga. Hal ini karena mereka yang menyiapkan konsumsi pangan dalam rumah tangganya. Penelitian ini bertujuan memahami bagaimana perempuan beradaptasi terhadap perubahan iklim, terutama dalam menjaga ketahanan pangan keluarga. Penelitian ini merupakan penelitian kualitatif. Pengumpulan data dilakukan melalui observasi, wawancara, dan dokumentasi. Daerah yang diobservasi adalah Kota Depok dan Kabupaten Bogor. Simpulan dari penelitian ini adalah perempuan yang tinggal di kota dan di desa miliki cara beradaptasi yang berbeda. Perempuan perkotaan memanfaatkan teknologi pertanian, sedangkan perempuan perdesaan melakukan diversifikasi jenis pangan. Hal ini terkait erat dengan ketersediaan lahan bagi keluarga mereka.
\end{abstract}

Kata kunci: adaptasi, perempuan, perubahan iklim 


\section{Pendahuluan}

Indonesia memiliki letak geografis di antara dua samudra, yakni Samudra Hindia dan Samudra Pasifik, di antara dua benua, yakni Benua Asia dan Benua Australia, serta terletak di khatulistiwa. Letak geografis ini menyebabkan Indonesia rentan terhadap perubahan iklim yang tengah terjadi saat ini. Perubahan iklim ini menyebabkan bencana alam dan cuaca seperti badai, banjir, kekeringan, dan tanah longsor. Pada bagian Penjelasan Undang-Undang Republik Indonesia Nomor 32 Tahun 2009 tentang Perlindungan dan Pengelolaan Hidup (selanjutnya disebut dengan UU PPLH) [1] telah dijelaskan bahwa Indonesia berlokasi pada posisi yang rentan terhadap dampak perubahan iklim yang meliputi antara lain turunnya produksi pangan, terganggunya ketersediaan air, tersebarnya hama dan penyakit tanaman serta penyakit manusia. Definisi perubahan iklim yang tercantum pada Pasal 1 butir 19 UU PPLH [1] adalah "berubahnya iklim yang diakibatkan langsung atau tidak langsung oleh aktivitas manusia sehingga menyebabkan perubahan komposisi atmosfir secara global dan selain itu juga berupa perubahan variabilitas iklim alamiah yang teramati pada kurun waktu yang dapat dibandingkan." Oleh karena itu, Pemerintah Indonesia memandang perlu adanya upaya-upaya menghadapi dampak perubahan iklim ini.

Penelitian tentang pengaruh perubahan iklim terhadap pertanian telah banyak dilakukan. Perubahan iklim berdampak pada perubahan waktu musim tanam yang terjadi antara dua sampai empat minggu. Hal ini mengakibatkan penurunan produksi dan produktivitas, fluktuasi harga produk pertanian, serta peningkatan jumlah penduduk yang berisiko kelaparan dan ketidakamanan pangan [2]. Perubahan iklim juga berpotensi memengaruhi secara signifikan mata pencaharian petani skala kecil, baik dengan menurunkan atau meningkatkan panen tanaman, tergantung jenis tanamannya [3].

Mengingat dampak perubahan iklim begitu besar terhadap pertanian, yang hasilnya berupa bahan pangan, maka manusia perlu melakukan adaptasi. Adaptasi perubahan iklim, di dalam Penjelasan UU PPLH [1], diartikan sebagai "upaya yang dilakukan untuk meningkatkan kemampuan dalam menyesuaikan diri terhadap perubahan iklim, termasuk keragaman iklim dan kejadian iklim ekstrim sehingga potensi kerusakan akibat perubahan iklim berkurang, peluang yang ditimbulkan oleh perubahan iklim dapat dimanfaatkan, dan konsekuensi yang timbul akibat perubahan iklim dapat diatasi." Tanpa tindakan drastis saat ini, upaya beradaptasi dengan dampak dari perubahan iklim di masa mendatang akan lebih sulit dan mahal [4]. Mengingat kondisi sosial ekonomi penduduk di Indonesia rentan terhadap bencana alam dan cuaca seperti badai, banjir, kekeringan, longsor, dan kebakaran hutan, maka pemerintah harus segera melaksanakan program adaptasi terhadap perubahan iklim tersebut.

Kaum perempuan, khususnya ibu rumah tangga, berperan dalam menyiapkan hidangan makanan sehari-hari bagi keluarganya. Perubahan iklim dapat mengakibatkan kegagalan panen sehingga memengaruhi ketersediaan bahan pangan di masyarakat. Sulitnya pasokan bahan pangan akan mempersulit ibu rumah tangga dalam menyiapkan hidangan untuk keluarganya. Dengan demikian, sulitnya pasokan bahan pangan ditambah dengan terganggunya ketersediaan air bersih akan memberikan dampak negatif terhadap kaum perempuan.

Tujuan dari penelitian ini adalah untuk mengkaji secara empiris perilaku adaptasi masyarakat Indonesia, khususnya perempuan, dalam menghadapi masalah yang ditimbulkan oleh perubahan iklim. Adaptasi perilaku dalam konteks penelitian ini terkait dengan pengadaan bahan pangan dan diversifikasi makanan yang disediakan dalam rumah tangga, sebagai bentuk antisipasi masyarakat saat bencana alam muncul akibat perubahan iklim. 


\section{Metode}

Penelitian ini merupakan penelitian kualitatif, berupa kajian empiris terhadap peran perempuan terutama ibu rumah tangga dalam beradaptasi terhadap perubahan iklim melalui pengadaan pangan bagi rumah tangganya. Pengumpulan data dilakukan melalui observasi, wawancara dengan informan, dan dokumentasi. Lokasi observasi adalah Kota Depok dan perdesaan di wilayah Kabupaten Bogor.

\section{Pembahasan}

Perubahan iklim memberikan dampak negatif yang besar terhadap sektor pertanian. Dampak negatif tersebut antara lain berupa ketidakpastian pola musim dan ketersediaan air yang berasal dari curah hujan. Waktu tanam dipengaruhi oleh musim hujan dan musim kemarau, dengan pertimbangan ada-tidaknya air untuk pengairan tanaman dan cukuptidaknya paparan sinar matahari. Namun akibat perubahan iklim, perguliran musim sulit diprediksikan. Petani menyangka bahwa musim hujan akan datang, ternyata musim kemarau berkepanjangan. Akibatnya, waktu tanam pun menjadi kacau. Dampak akhirnya adalah ketidakpastian pasokan bahan pangan di masyarakat. Di sinilah ibu rumah tangga mengalami kesulitan dalam menyediakan makanan untuk keluarga, apalagi kaum perempuan dari keluarga miskin. Hal ini menunjukkan betapa dampak perubahan iklim sangat memengaruhi kehidupan 1,3 miliar penduduk miskin dunia yang mayoritas adalah kaum perempuan [5].

Di Indonesia, petani berskala kecil yang termasuk masyarakat kurang sejahtera sangat merasakan dampak dari perubahan iklim. Ketidakpastian waktu musim tanam, terutama waktu panen yang semakin berlarut, menyebabkan menurunnya kemampuan petani untuk bercocok tanam sehingga keadaannya semakin rentan. Masyarakat yang rentan adalah masyarakat yang memiliki ketergantungan tinggi pada sumber daya alam dan memiliki kapasitas yang terbatas untuk mengatasi variabilitas iklim yang ekstrem [4]. Dalam hal ini, petani perlu beradaptasi secara efektif untuk mengurangi efek variabilitas iklim dan membangun ketahanan pangan mereka [3]. Adaptasi terhadap perubahan iklim perlu dilakukan guna meningkatkan produksi pangan, selain untuk menunjang kehidupan petani dan pengadaan bahan pangan untuk masyarakat.

Beras adalah salah satu produk pertanian yang sangat diperlukan oleh masyarakat Indonesia. Hal ini karena makanan pokok sumber karbohidrat dan energi mayoritas masyarakat Indonesia adalah nasi yang merupakan olahan dari beras. Beras telah menjadi makanan pokok yang sangat dominan di Indonesia, termasuk di daerah-daerah yang sebelumnya mempunyai pola pangan pokok bukan beras [6][7]. Contohnya, daerah Madura yang sebelumnya mengonsumsi makanan pokok beras jagung.

Sebagian informan yang diwawancarai mengatakan bahwa "Belum makan nasi, berarti belum makan.” Informan menggambarkan, sekalipun sudah makan mi instan dua bungkus, mereka masih menganggap dirinya belum makan jika belum makan nasi. Akibat kebiasaan ini, masyarakat Indonesia termasuk pengonsumsi beras terbesar di dunia, dengan tingkat konsumsi $154 \mathrm{~kg}$ per orang per tahun [8]. Pulau Jawa merupakan pulau subur yang menjadi lumbung padi bagi penduduknya, tetapi sekarang daerah persawahannya sudah banyak yang dikonversi menjadi permukiman dan kawasan industri, sehingga produksi berasnya merosot dan harus mengimpor beras dari luar negeri. Besarnya impor beras di Indonesia disebabkan oleh peningkatan jumlah penduduk dan tingkat konsumsi yang lebih besar daripada produksinya 
[8]. Dengan adanya ancaman perubahan iklim, ketergantungan bangsa Indonesia akan beras membuatnya menjadi rentan. Oleh karena itu, pola pikir masyarakat yang tergantung pada beras harus diubah. Kearifan lokal yang dimiliki masyarakat Indonesia adalah masyarakat pengonsumsi berbagai jenis pangan sumber energi. Di samping beras/nasi, masyarakat Indonesia juga mengonsumsi jagung, sagu, singkong, ganyong, gadung, ubi jalar, dan lainlain. Tabel 1 di bawah ini menyajikan kandungan gizi dari beberapa jenis makanan sumber energi yang mudah diperoleh di Indonesia [9].

Tabel 1. Kandungan gizi beberapa jenis bahan pangan pokok di Indonesia (per 100 gram)

\begin{tabular}{lcccc}
\hline \multicolumn{1}{c}{ Jenis pangan } & Energi $(\mathrm{kal})$ & Protein $(\mathrm{g})$ & Lemak $(\mathrm{g})$ & Karbohidrat $(\mathrm{g})$ \\
\hline Beras giling & 357 & 8,4 & 1,7 & 77,1 \\
Nasi & 180 & 3,0 & 0,3 & 39,8 \\
Gadung segar & 100 & 0,9 & 0,3 & 23,5 \\
Ganyong segar & 77 & 0,6 & 0,2 & 18,4 \\
Tepung Gaplek & 345 & 2,4 & 0,4 & 83,1 \\
Beras jagung putih & 307 & 4,8 & 0,1 & 71,8 \\
Singkong segar & 154 & 1,0 & 0,3 & 36,8 \\
Sagu aren kering & 355 & 0,6 & 1,1 & 85,6 \\
\hline
\end{tabular}

Dari Tabel 1 tampak bahwa masih banyak pilihan makanan pokok sumber karbohidrat dan energi yang dapat diperoleh penduduk di Indonesia dengan kandungan gizi yang tidak kalah baiknya dengan nasi. Sebagai contoh, makanan pokok orang Madura, yaitu beras jagung, memiliki kandungan gizi yang lebih baik daripada nasi; sama halnya dengan sagu yang merupakan makanan pokok orang Maluku dan Papua pesisir, kandungan gizinya lebih tinggi daripada nasi.

Hasil wawancara dengan informan juga menunjukkan bahwa mereka mengonsumsi tahu, tempe, dan kecap hampir setiap hari. Tahu, tempe, dan kecap merupakan sumber protein nabati yang berasal dari kacang kedelai. Menurut informan, harga daging sebagai sumber protein hewani itu mahal, sehingga tahu atau tempe yang dibarengi dengan kecap menjadi pilihan lauk mereka sehari-hari. Ironisnya, kedelai sebagai bahan baku utama tempe, tahu, dan kecap, sebagian besar diimpor dari mancanegara. Indonesia termasuk negara pengimpor kedelai terbesar di dunia, karena konsumsi dalam negeri meningkat, tetapi produksinya hanya mencukupi 15 persen dari kebutuhan domestik [10]. Jika kebutuhan kacang kedelai dapat dipenuhi oleh produksi dalam negeri, maka tempe, tahu, dan kecap dapat dibeli dengan harga yang lebih murah, sehingga kebutuhan akan protein penduduk Indonesia dapat terpenuhi.

Sumber protein nabati kerap dikonsumsi untuk melengkapi sumber protein hewani yang harganya fluktuatif dan relatif tinggi, seperti daging sapi yang sebagian masih diimpor. Pemenuhan kebutuhan daging selama kurun lima tahun (2010-2014) rata-rata terdiri atas 73,98 persen produk lokal dan sisanya 26,02 persen produk impor [11]. Kementerian Pertanian mencatat impor daging dan jeroan sapi/kerbau sebesar 68.125 ton hingga Juli 2020, setara dengan 18 persen dari rekomendasi impor yang diberikan pemerintah untuk tahun 2020, yaitu 379.050 ton [12]. Oleh karena itu, untuk mencukupi kebutuhan protein dan lemak, maka kebiasaan memakan ikan sebagai sumber protein dan lemak hewani perlu digalakkan. Indonesia sebagai negara bahari memiliki keanekaragaman biota air yang berlimpah yang dapat dijadikan alternatif sumber protein dan lemak hewani, baik dari hasil perikanan air tawar maupun perikanan laut.

Hasil wawancara dengan informan menggambarkan kebutuhan mereka akan jenis bahan pangan tertentu sebagai sumber energi dan protein. Namun, perubahan iklim telah menyebabkan ibu rumah tangga mengalami kesulitan dalam memenuhi kebutuhan 
keluarganya. Kelangkaan pasokan bahan pangan di pasar akan menyebabkan harga semakin mahal. Hal ini akan memperparah kondisi keuangan dan memengaruhi ketahanan pangan keluarga. Ibu rumah tangga harus dapat mengubah menu hidangan sehari-hari dengan makanan pokok yang bervariasi-tidak harus memakan nasi. Di samping itu, mereka juga perlu mendiversifikasi lauk pauk sumber protein dan lemak.

Ibu rumah tangga berperan sebagai pendidik untuk anak-anaknya. Oleh karena itu, mereka berperan membiasakan anak-anak sejak usia dini untuk mengonsumsi berbagai jenis makanan pokok dan lauk pauk. Sang ibu berperan dalam menentukan komposisi menu dan mengolah bahan makanan, sedangkan sang ayah sebagai kepala keluarga berperan dalam menentukan dan mendukung kebijakan sang ibu tersebut. Kekompakan dalam keluarga akan menentukan keberhasilan dalam melaksanakan kebijakan guna mencegah kondisi kekurangan gizi pada saat beras dan bahan pangan sumber protein menjadi langka dan mahal.

Sebagai pengolah bahan baku menjadi hidangan, ibu rumah tangga harus memutar otak untuk tetap dapat menyediakan makanan bagi keluarganya agar tidak mengalami kelaparan. Semakin langka bahan pangan, semakin mahal harganya. Seluruh anggota keluarga dapat menderita kelaparan, bahkan kekurangan gizi. Namun, ada kendala yang dihadapi oleh ibu rumah tangga di Indonesia, yaitu kurangnya pengetahuan mereka tentang gizi dan asupan makanan untuk keluarga. Dari hasil wawancara diketahui bahwa ibu rumah tangga masih mementingkan rasa kenyang yang berasal dari kuantitas nasi yang dikonsumsi dibandingkan nilai gizi dari keseluruhan hidangan. Padahal kandungan gizi dari makanan yang masuk tubuh manusia haruslah seimbang. Ini penting untuk menjaga dan meningkatkan kesehatan dan ketahanan tubuh, sehingga dapat mencegah timbulnya penyakit.

Dengan adanya kelangkaan bahan pangan akibat perubahan iklim, kaum ibu perlu melakukan upaya-upaya untuk memenuhi kebutuhan pangan keluarganya. Berdasarkan hasil analisis data, bentuk-bentuk upaya adaptasi terhadap perubahan iklim dalam rangka ketahanan pangan keluarga tergantung pada lokasi di mana para informan berdomisili, yakni di daerah perkotaan ataukah perdesaan.

Perumahan di lingkungan perkotaan pada umumnya memiliki halaman yang terbatas, tidak luas, sehingga tidak mudah untuk menanam tanaman pangan di halaman rumah. Di samping itu, mayoritas penduduk kota memiliki mata pencaharian di luar bidang pertanian, sehingga memiliki keterampilan bertani yang terbatas. Namun demikian, dengan adanya informasi mengenai teknologi pertanian untuk lahan yang terbatas, kaum perempuan di perkotaan mampu mempelajari teknologi untuk menanam sayuran dan memelihara ikan bagi keperluan subsistensi keluarga. Teknologi pertanian untuk lahan terbatas yang digunakan di perkotaan antara lain hidroponik dan budikdamber. Hidroponik tidak membutuhkan air dan lahan yang terlalu banyak. Berbagai jenis sayuran, bahkan buah-buahan, dapat ditanam dengan cara hidroponik (lihat Gambar 1). Budikdamber merupakan singkatan dari budi daya ikan dalam ember (lihat Gambar 2). Dengan cara ini, para ibu dapat membudidayakan ikan lele sekaligus memelihara tanaman kangkung yang diletakkan di atasnya. Jelas ember tidak membutuhkan banyak lahan dan airnya pun diganti seminggu sekali. Ini adalah cara perempuan perkotaan beradaptasi dengan perubahan iklim untuk menyediakan ikan konsumsi dan sayur-mayur agar ketahanan pangan keluarga tetap terjaga. 


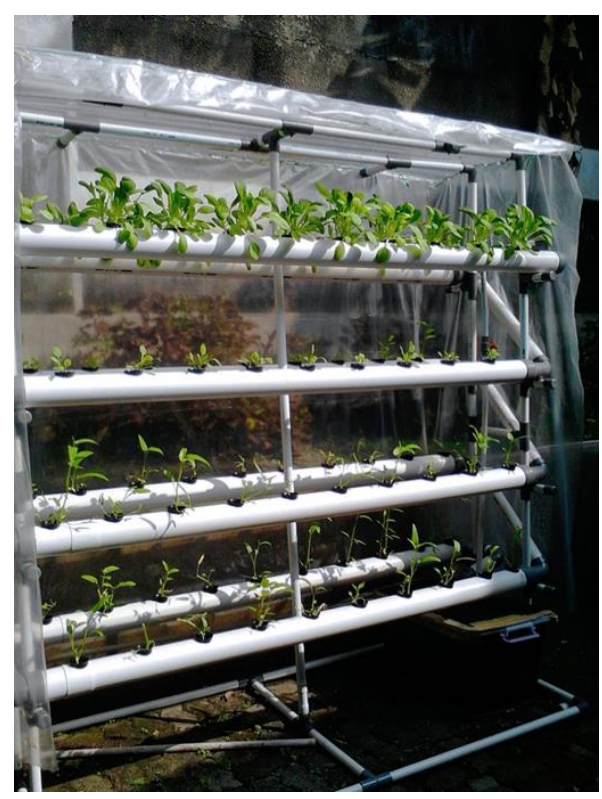

Gambar 1. Hidroponik.

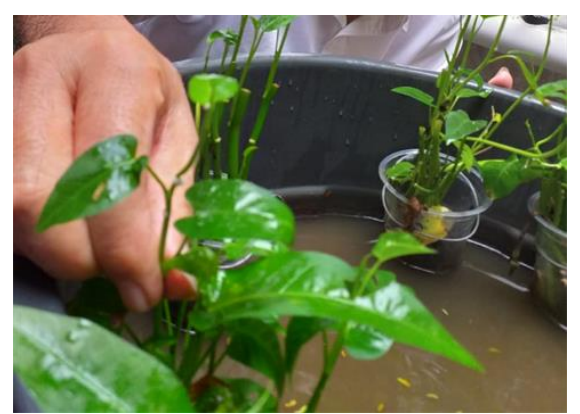

Gambar 2. Budikdamber.

Perempuan perdesaan memiliki cara yang berbeda dalam beradaptasi demi menjaga ketahanan pangan keluarga. Rumah di perdesaan pada umumnya memiliki halaman yang masih cukup luas, sehingga bisa ditanami dengan berbagai tanaman pangan untuk keperluan keluarga. Keluarga perdesaan, jika mengalami kesulitan untuk panen padi, akan melakukan diversifikasi bahan pokok makanan dengan umbi-umbian. Umbi-umbian yang biasa mereka konsumsi antara lain singkong, ubi jalar, kentang, ganyong, uwi, talas, dan gembili. Di daerah yang panen singkongnya berlimpah, singkong kerap dijadikan tepung tapioka, gaplek, atau tepung gaplek. Dengan demikian, masih memungkinkan bagi masyarakat perdesaan untuk memperoleh alternatif bahan pokok sumber karbohidrat dan energi. Namun, mereka cenderung kurang memperhatikan kandungan nutrisi dalam makanan yang mereka konsumsi, karena lebih menekankan pada rasa kenyang. Adapun untuk sumber protein, di perdesaan cukup banyak, khususnya protein hewani. Hal ini karena rata-rata penduduk desa memelihara hewan ternak maupun ikan konsumsi di empang atau kolam. 
Dampak dari perubahan iklim juga dapat berupa timbulnya berbagai penyakit yang menyerang manusia. Oleh karena itu, ketahanan tubuh menjadi penting. Untuk meningkatkan ketahanan tubuh, diperlukan asupan makanan yang bergizi dan berimbang. Ibu rumah tangga yang mengelola hidangan dalam keluarganya perlu menguasai pengetahuan terkait gizi yang berimbang ini. Menurut Pasal 2 Peraturan Menteri Kesehatan Nomor 28 Tahun 2019 tentang Angka Kecukupan Gizi yang Dianjurkan untuk Masyarakat Indonesia, angka kecukupan gizi (AKG) digunakan pada tingkat konsumsi yang meliputi kecukupan energi, protein, lemak, karbohidrat, serat, air, vitamin, dan mineral [13]. Dengan demikian, ragam lauk pauk pun perlu diperhatikan. Di sinilah peran pemerintah dalam menyosialisasikan makanan yang bergizi untuk masyarakat Indonesia sesuai dengan tempat tinggal dan kebiasaan mereka agar terhindar dari bahaya kekurangan gizi.

Menurut data BPS tahun 2019, populasi penduduk Indonesia mencapai 268.074.600 jiwa. Jumlah populasi perempuan Indonesia adalah 133.416.900 jiwa [14] atau 49,63\% dari total penduduk Indonesia. Di samping itu, jumlah rumah tangga (household) di Indonesia adalah 68.700.700 rumah tangga, dengan rata-rata banyaknya anggota rumah tangga 3,9 jiwa [15]. Data ini menunjukkan bahwa satu perempuan menyiapkan hidangan untuk empat orang, termasuk dirinya sendiri, sekaligus menunjukkan betapa pentingnya peran ibu rumah tangga dalam penyediaan pangan keluarga.

Tingkat pendidikan akan memengaruhi tingkat pemahaman masyarakat terhadap risiko perubahan iklim dan dampaknya [16]. Dari segi pendidikan, masih ada kesenjangan pendidikan antara laki-laki dan perempuan, baik yang berdomisili di perkotaan maupun di perdesaan (lihat Gambar 3). Tingkat pendidikan laki-laki lebih tinggi daripada perempuan [15]. Rendahnya tingkat pendidikan akan memengaruhi cara penyampaian informasi saat sosialisasi tentang dampak perubahan iklim dan diversifikasi pangan serta gizi berimbang kepada masyarakat.

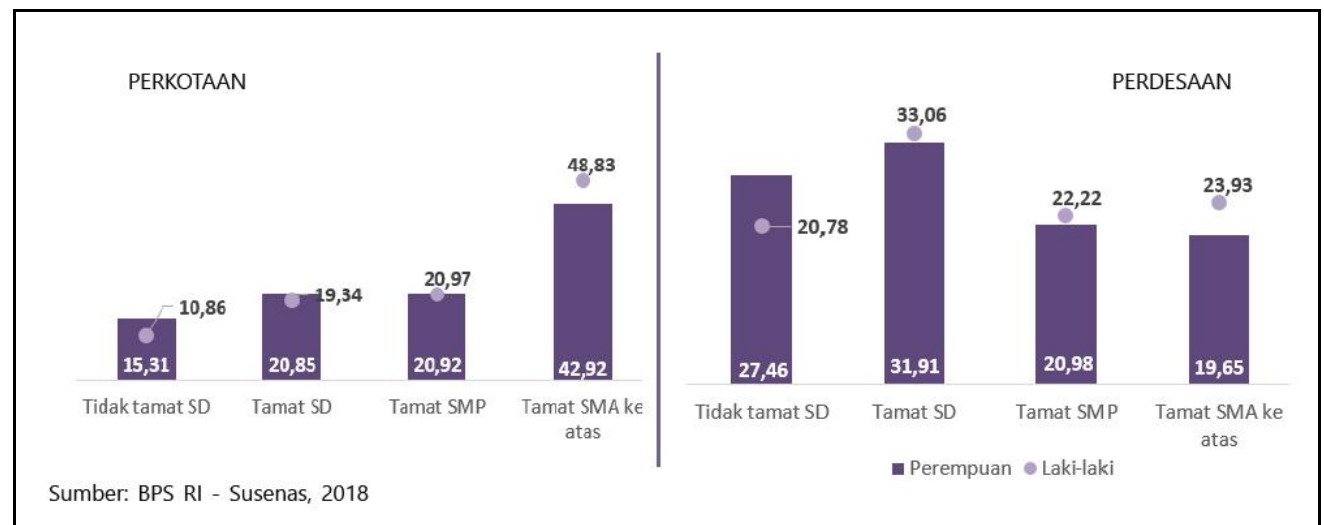

Gambar 3. Persentase penduduk usia 15 tahun ke atas menurut daerah tempat tinggal, jenis kelamin, dan pendidikan tertinggi yang ditamatkan tahun 2018 [15]

Rendahnya tingkat pendidikan perempuan dapat memengaruhi tingkat penerimaan informasi dan ketercapaian pemahaman dalam kegiatan sosialisasi. Hal ini dapat disebabkan oleh penggunaan istilah bahasa atau cara komunikasi yang kurang mudah dipahami oleh target sasaran (pendengar). Oleh karena itu, kegiatan sosialisasi perlu menggunakan metode demonstrasi dengan menyertakan contoh-contoh tentang dampak perubahan iklim dan cara beradaptasi terhadapnya melalui diversifikasi pangan dengan mengombinasikan menu 
makanan pokok dan lauk pauk yang memenuhi angka kecukupan gizi. Peniruan adalah hal yang lebih mudah untuk dikerjakan, maka program sosialisasi tanpa demonstrasi memasak tidak akan menarik dan memberikan manfaat bagi perempuan yang memiliki keterbatasan sumber daya. Penggunaan metode demonstrasi akan mendorong peserta sosialisasi untuk berperan aktif dan berani mengemukakan pendapat serta mendemonstrasikan materi ajar sehingga peserta lain dapat mengerti dengan baik [17].

Sosialisasi merupakan bagian dari program ketahanan pangan sebagai salah satu langkah adaptasi terhadap perubahan iklim yang harus dilaksanakan secara komprehensif. Oleh karena itu, sosialisasi harus dilakukan bersamaan dengan penyediaan keanekaragaman bahan pangan yang bergizi. Pemerintah dan masyarakat sipil memiliki peran penting dalam meningkatkan kesadaran masyarakat akan perubahan iklim dan melindungi alam, serta mengakhiri kerentanan perempuan [5] [16]. Masyarakat yang memiliki pengetahuan dan menguasai teknologi dapat bekerja sama dengan pemerintah dalam membantu ibu rumah tangga mengembangkan diri untuk menghadapi dampak perubahan iklim. Masalah perubahan iklim adalah masalah bersama. Oleh karena itu, kerja sama antara pemerintah dan masyarakat diharapkan akan memberikan hasil yang optimal dalam beradaptasi menghadapi perubahan iklim.

\section{Simpulan}

Salah satu dampak negatif perubahan iklim terhadap kaum perempuan, khususnya ibu rumah tangga, adalah terjadinya kelangkaan bahan pangan. Perempuan yang berdomisili di perdesaan memiliki cara beradaptasi yang berbeda dengan perempuan yang berdomisili di perkotaan dalam menjaga ketahanan pangan keluarga. Hal ini terkait dengan ketersediaan lahan untuk mengusahakan bahan pangan bagi keluarga mereka. Perempuan, khususnya ibu rumah tangga, dapat beradaptasi melalui teknologi dan diversifikasi bahan pangan. Selain itu, perlu adanya sosialisasi tentang risiko dan dampak perubahan iklim, serta sosialisasi tentang diversifikasi pangan dan gizi berimbang kepada ibu rumah tangga sebagai bagian dari program adaptasi masyarakat menghadapi perubahan iklim.

\section{Referensi}

[1] Pemerintah Indonesia. Undang-undang Nomor 32 Tahun 2009 tentang Perlindungan dan Pengelolaan Lingkungan Hidup. Jakarta: Sekretariat Negara. 2009.

[2] Muslim C. Mitigasi Perubahan Iklim dalam Mempertahankan Produktivitas Tanah Padi Sawah (Studi kasus di Kabupaten Indramayu). Jurnal Penelitian Pertanian Terapan. 2013. 13(3): 211-222.

[3] Ochieng J, Kirimi, L, Mathenge, M. Effects of climate variability and change on agricultural production: The case of small scale farmers in Kenya. NJAS - Wageningen Journal of Life Sciences, 2016. 77(2016): 71-78. https://doi.org/10.1016/j.njas.2016.03.005

[4] Adedeji, O, Reuben, O, Olatoye, O. Global climate change. Journal of Geoscience and Environment Protection, 2014. 2(April): 114-122. https://doi.org/10.1007/978-94-007-7353-0_3

[5] Dimitrov BEG. Effects of Climate change on Women. Research Review International Journal Of Multidisciplinary. 2019. 4(5). 210-215. ISSN: 2455-3085 (Online).

[6] Nuryani. Potensi Subtitusi Beras Putih Dengan Beras Merah Sebagai Makanan Pokok Untuk Perlindungan Diabetes Melitus. Media Gizi Masyarakat Indonesia. 2013. 3(3): 157-168. 
[7] Suryani N, Abdurrachim R, Alindah N. Analisis Kandungan Karbohidrat, Serat Dan Indeks Glikemik Pada Hasil Olahan Beras Siam Unus Sebagai Alternatif Makanan Selingan Penderita Diabetes Mellitus. Jurkessia. 2016. VII(1): 1-9.

[8] Febriaty H. Analisis Perkembangan Impor Beras di Indonesia. Ekonomikawan: Jurnal Ilmu Ekonomi dan Studi Pembangunan. 2016. 16: 134-141. 10.30596/ekonomikawan.v16i2.941.

[9] Kementerian Kesehatan RI. Tabel Komposisi Pangan Indonesia 2017. Jakarta: Direktorat Jenderal Kesehatan Masyarakat Kementerian Kesehatan Republik Indonesia. 2018.

[10] Mahdi NN, Suharno. Analisis Faktor-Faktor Yang Memengaruhi Impor Kedelai Di Indonesia. Forum Agribisnis: Agribusiness Forum. 2019. 9(2): 160-184. ISSN 2252-5491, E-ISSN 2656-4599. DOI: https://doi.org/10.29244/fagb.9.2.160-184.

[11] Jiuhardi. Kajian Tentang Impor Daging Sapi Di Indonesia. Forum Ekonomi. 2016. 17(2):75-91.

[12] CNN Indonesia. RI Impor Daging dan Jeroan 68 Ribu Ton hingga Juli. CNN Indonesia Rabu, 15/07/2020. https://www.cnnindonesia.com/ekonomi/20200715150214-92-524997/ri-impordaging-dan-jeroan-68-ribu-ton-hingga-juli

[13] Kementerian Kesehatan RI. Peraturan Menteri Kesehatan Nomor 28 Tahun 2019 tentang Angka Kecukupan Gizi Yang Dianjurkan Untuk Masyarakat Indonesia. Jakarta: Kementerian Kesehatan Republik Indonesia. 2019.

[14] Badan Pusat Statistik. Statistik Indonesia 2020. ISSN: 0126-2912. Jakarta: Badan Pusat Statistik Indonesia. 2020.

[15] Kementerian Pemberdayaan Perempuan dan Perlindungan Anak RI. Profil Perempuan Indonesia 2019. ISSN: 2089-3515. Jakarta: Kementerian Pemberdayaan Perempuan dan Perlindungan Anak Republik Indonesia. 2019.

[16] Pratiwi NAH, Rahmawati YD, Setyono I. Gender equality in climate change adaptation: A case of Cirebon, Indonesia. The Indonesian Journal of Planning and Development. 2017. 2(2), 74-86. doi:10.14710/ijpd.2.2.74-86.

[17] Sobon K, Lumowa SJ. Penggunaan Metode Demonstrasi Untuk Peningkatan Hasil Belajar Siswa Kelas V Pada Mata Pelajaran IPA di SD Negeri Kawangkoan Kecamatan Kalawat. Jurnal Pendidikan Dasar Nusantara. 2018(Januari). 3(2): 196-207. ISSN 2579-6461 (Online) ISSN 24606324 (Print). 